\title{
A fractured tuberosity following attempted extraction
}

\author{
S L McKernon, ${ }^{1}$ S Reid, ${ }^{2}$ K H Taylor, ${ }^{1}$ M C Balmer ${ }^{2}$
}

${ }^{1}$ School of Dentistry, University of Liverpool, Liverpool, UK ${ }^{2}$ Department of Oral Surgery, Liverpool Dental Hospital, Liverpool, UK

\section{Correspondence to}

S L McKernon,

s.l.mckernon@liv.ac.uk

Accepted 5 December 2015

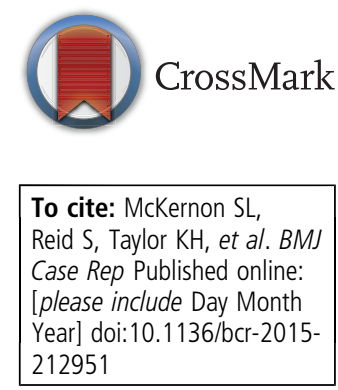

\section{DESCRIPTION}

A 53-year-old man presented to the A\&E department at Liverpool University Dental Hospital following urgent referral from his general dental practitioner. During attempted routine extraction of the 18 (upper right wisdom tooth), his general dental practitioner had noticed the palate tearing and the tuberosity displace during the procedure and stopped. Clinical and radiographic examination demonstrated a fractured tuberosity with associated lacerated soft palatal tissue (figures 1 and 2). The tuberosity and fractured tooth were grossly mobile and required stabilisation. Ideal management for this complication is a wire and composite splint in place for 6 weeks to allow for bony union.

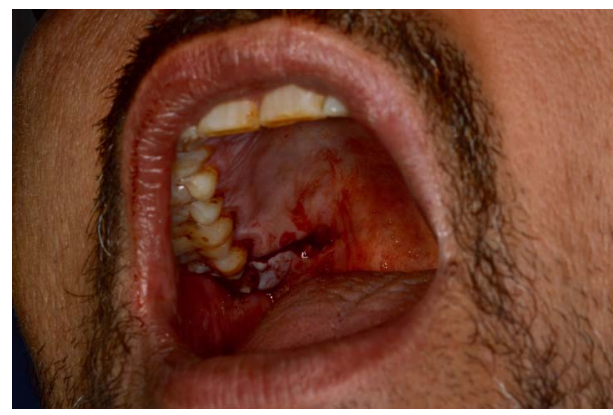

Figure 1 Intra-oral photo demonstrating palatal tear.

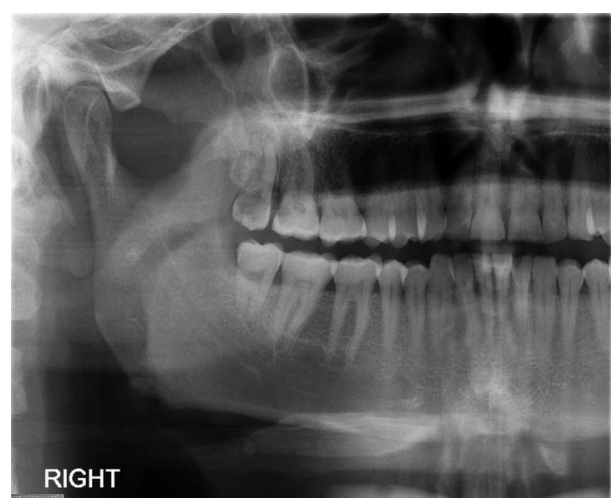

Figure 2 Orthopantomogram demonstrating fracture line mesial to 18.

Following healing, an elective surgical procedure was performed to remove the remaining tooth. This image highlights a complication many patients are warned of but that few professionals will encounter in their careers.

Acknowledgements The authors would like to acknowledge the hard work of the staff within the oral diagnosis department in assisting in the care of the patient.

Competing interests None declared.

Patient consent Obtained.

Provenance and peer review Not commissioned; externally peer reviewed.

Copyright 2015 BMJ Publishing Group. All rights reserved. For permission to reuse any of this content visit http://group.bmi.com/group/rights-licensing/permissions.

BMJ Case Report Fellows may re-use this article for personal use and teaching without any further permission.

Become a Fellow of BMJ Case Reports today and you can:

- Submit as many cases as you like

- Enjoy fast sympathetic peer review and rapid publication of accepted articles

- Access all the published articles

- Re-use any of the published material for personal use and teaching without further permission

For information on Institutional Fellowships contact consortiasales@bmjgroup.com

Visit casereports.bmj.com for more articles like this and to become a Fellow 